\title{
Penggunaan Model Pembelajaran Berbasis Proyek dengan Menggunakan Audio Video untuk Meningkatkan Hasil Belajar Siswa
}

\author{
Lugiati* $^{*}$ \\ SMK N I Dlanggu, Mojokerto, Indonesia
}

\author{
A R T I C L E I N F O \\ Article history: \\ Received 19 August 2020 \\ Received in revised form \\ 30 September 2020 \\ Accepted 10 October 2020 \\ Available online 29 \\ November 2020

\section{Kata Kunci:} \\ Pembelajaran Berbasis \\ Proyek, Audio Video \\ Keywords: \\ Project Based Learning, \\ Audio Video
}

\begin{abstract}
A B S T R A K
Penelitian ini bertujuan untuk menganalisis hasil belajar siiswa setelah dibelajarkan dengan model berbasis proyek dengan bnatuan Audio Video. Jenis penelitian yang digunakan adalah penelitian tindakan kelas dengan model Kemmis dan Mc Taggart yang mencakup perencanaan, pelaksanaan, pengamatan, dan refleksi. Subjek penelitian berjumlah 34 siswa. Teknik pengambilan data melalui lembar observasi, lembar penilaian unjuk kerja, tes pilihan ganda, dan dokumentasi. Data dianalisis secara deskriptif. Hasil penelitian menunjukkan: Rata-rata keterlaksanaan pembelajaran pada siklus pertama mencapai persentase $75 \%$, pada siklus kedua meningkat menjadi 100\%; 3) penerapan model pembelajaran berbasis proyek terhadap materi produk cake dan kue Indonesia dari tepung ketan dan umbi-umbian dapat meningkatkan hasil belajar. Nilai rata-rata kelas pada pra siklus sebesar 81,4, menjadi 83,5
\end{abstract} pada siklus pertama dan 91,2 pada siklus kedua. Siswa yang mencapai kriteria ketuntasan minimal (KKM) pada pra siklus sebesar $80 \%$, meningkat $3 \%$ menjadi $83 \%$ pada siklus pertama dan meningkat $17 \%$ menjadi $100 \%$ pada siklus kedua. Jadi, dapat dikatakan bahwa model berbasis proyek berbatuan audio video dapat meningkatkan hasil belajar siwa

\section{A B S T R A C T}

This study aims to analyze student learning outcomes after being taught with a project-based model with Audio Video rockets. The type of research used is classroom action research with the model of Kemmis and Mc Taggart which includes planning, implementation, observation, and reflection. The research subjects were 34 students. Data collection techniques through observation sheets, performance assessment sheets, multiple choice tests, and documentation. Data were analyzed descriptively. The results showed: The average implementation of learning in the first cycle reached a percentage of $75 \%$, in the second cycle it increased to $100 \%$; 3) the application of a projectbased learning model to the material for Indonesian cake and cake products from glutinous rice flour and tubers can improve learning outcomes. The class average value in the pre-cycle was 81,4 , becoming 83,5 in the first cycle and 91,2 in the second cycle. Students who achieved the minimum completeness criteria (KKM) in the pre-cycle were $80 \%$, increased $3 \%$ to $83 \%$ in the first cycle and increased $17 \%$ to $100 \%$ in the second cycle. So, it can be said that the audio video-based projectbased model can improve student learning outcomes.

\section{Pendahuluan}

Dunia pendidikan saat ini semakin berkembang, berbagai macam, pembaharuan dilakukan agar dapat meningkatkan kualitas dan kuantitas pendidikan. Untuk meningkatkan kualitas pendidikan diperlukan berbagai terobosan baik dalam pengembangan kurikulum, inovasi pembelajaran, dan pemenuhan sarana serta prasarana pendidikan. Untuk meningkatkan proses pembelajaran, maka guru 
dituntut untuk membuat pembelajaran menjadi lebih inovatif yang mendorong siswa dapat belajar secara optimal baik di dalam belajar mandiri maupun didalam pempelajaran di kelas. Pendidikan memilki peranan penting guna meningkatkan kualitas sumber daya manusia. Bagi manusia, pendidikan berfungsi sebagai sarana dan fasilitas yang memudahkan, mampu mengarahkan, mengembangkan dan membimbing ke arah kehidupan yang lebih baik, tidak hanya bagi diri sendiri melainkan juga bagi manusia lainnya.

Pendidikan memegang peranan penting yang menyangkut kemajuan dan masa depan bangsa, tanpa pendidikan yang baik mustahil suatu bangsa akan maju. Dalam rangka meningkatkan mutu pendidikan di Indonesia saat ini adalah dengan cara mengubah paradigm pendidikan. Pada pembelajaran yang lampau guru biasanya lebih banyak menghabiskan waktunya untuk berbicara dan sedikit memberikan kesan lain dalam pembelajaran. Hal ini yang membuat atmosfir pembelajaran di dalam kelas menjadi membosankan. Pendidikan di Indonesia memiliki tujuan untuk mengembangkan manusia menjadi manusia yang utuh. Mengembangkan siswa menjadi manusia yang utuh tentu bukan hanya meningkatkan kemampuan pada tingkat kognitif, melainkan juga afektif dan psikomotorik (Marcella, 2018).

Sekolah Menegah Kejuruan adalah salah satu jenis lembaga pendidikan formal yang menjadi salah satu alternatif sekolah lanjutan selain Sekolah Menengah Atas (SMA) dan Madrasah Aliyah (MA) bagi peserta didik yang ingin mendapat keahlian dalam suatu bidang tertentu. Sekolah Menegah Kejuruan dibangun atau didirikan untuk menciptakan lulusan agar siap kerja sesuai dengan minat dan bakatnya. Hal ini sesuai dengan pernyataan Peraturan Pemerintah No. 29 Tahun 1990 tentang Pendidikan Menegah Bab I Ayat 1 Pasal 3, bahwa "Pendidikan Menengah Kujuruan adalah pendidikan pada jenjang menegah yang mengutamakan pengembangan kemampuan siswa untuk melaksanakan jenis pekerjaan tertentu" (Kurikulum SMK:2006). Berdasarkan pernyataan tersebut jelas bahwa sekolah menengah kejuruan memfokuskan pada suau program keahlian atau program pendidikan tertentu. Pembaharuan sistem pendidikan dalam rangka meningkatkan mutu pendidikan, relevansi pendidikan, dan perubahan kurikulum mutlak diperlukan agar perkembangan pendidikan dapat mengikuti perkembangan jaman. Kurikulum 2013 merupakan kurikulum yang berorientasi pada serangkaian pengalaman belajar yang harus dicapai oleh peserta didik. Pada kurikulum 2013 peserta didik diharapkan mampu dengan mandiri mengembangkan potensi dalam dirinya untuk memenuhi kebutuhan dan tuntutan lingkungan. Salah satu mata pelajaran yang wajib ditempuh oleh siswa SMK bidang Jasa Boga adalah Produk Cake dan Kue Indonesia.

Berdasarkan pengamatan selama Kegiatan Belajar Mengajar dan observasi yang dilakukan pada peserta didik kelas XI Tata Boga 3 SMKN 1 Dlanggu-Mojokerto nampak para siswa kurang termotivasi dan kurang bersemangat dalam mengikuti pembelajaran Produk Cake dan Kue Indonesia . Kegiatan belajar mengajar selama ini tidak mampu menarik perhatian siswa, dengan metode ini guru cenderung tidak melibatkan siswa untuk aktif dalam pembelajaran. Media bantu yang digunakan guru selama pembelajaran hanya berbatas pada text book atau power point dan tidak mampu menarik perhatian siswa. Kurangnya motivasi dan perhatian siswa serta rendahnya prestasi belajar tersebut menunjukkan bahwa terjadi hambatan dalam proses pembelajaran yang menimbulkan terganggunya informasi yang seharusnya diterima oleh siswa. Hasil belajar peserta didik pada mata pelajaran yang dipelajari merupakan mengikuti mata pelajaran berikutnya. Keberhasilan peserta didik menempuh setiap bidang mata pelajaran merupakan bekal mewujudkan keahlian yang dimilikinya. Pemahaman akan kompetensi Produk cake dan Kue Indonesia menjadi hal perlu diperhatikan guna tercapai keberhasilan tujuan pembelajaran, tidak hanya pada hasil belajar saja. Tujuan pembelajaran pada dasarnya adalah kemampuan peserta didik memahami isi, maksud dan pesan yang diberikan oleh mata pelajaran tersebut.

Menutur penjelasan di atas jelas memperlihatkan bahwa kesiapan perangkat pembelajaran baik pembelajaran adaptif maupun produktif harus benar benar dilakukan oleh guru sehingga peserta didik akan termotivasi dalam mengikuti kegiatan pembelajaran. Peserta didik dalam proses belajar dibantu oleh seorang guru, tugas guru ialah membantu, membimbing peserta untuk mencapai mencapai tujuannya metedologi siswa pengajaran sampai kepada siswa, sehingga siswa mencapai tujuan pembelajaran. Dengan kata lain, untuk membantu kelancaran proses belajar mengajar guru dapat menggunakan model atau metode pembelajaran dan media bantu, media bantu dapat berupa model, buku teks, film transparansi, kaset video, dan lainnya.

Di dalam proses belajar mengajar agar pembelajaran efektif maka diperlukan suatu model dan media yang sesuai dengan karakter peserta didik, mata pelajaran yang disampaikan, suasana dan prasarana penunjang. Dengan perangkat pembelajaran yang baik akan menuntun siswa untuk dapat meningkatkan hasil belajar dengan baik. Untuk itu pada kompetensi Mengolah kue Indonesia berbahan dasar dari Tepung Ketan diperlukan pembelajaran yang menarik dan memudahkan peserta didik untuk memahami bagaimana jika terjadi kesalahan penanganan dalam proses pembuatan kue berbahan dasar dari tepung ketan, akan didapatkan hasil yang memunuhi standar atau kompetensi yang diharapkan. Salah satu model yang dipilih adalah model pembelajaran berbasis masalah. 
Sedangkan menurut Joel L dalam (Widyantini, 2014) Pembelajaran berbasis proyek adalah strategi pembelajaran yang memberdayakan siswa untuk memperoleh pengetahuan dan pemahaman baru berdasar pengalamannya melalui berbagai presentasi. PjBL merupakan model belajar yang menggunakan masalah sebagai langkah awal dalam mengumpulkan dan mengintegrasikan pengetahuan baru berdasarkan pengalamannya dalam beraktifitas secara nyata. Model PjBL adalah model pembelajaran yang memberikan kesempatan kepada guru untuk mengelola pembelajaran di kelas dengan melibatkan kerja proyek (Ratnasari et al., 2018; Mulyadi, 2016). Menurut (Aisah, 2014) Keuntungan Pembelajaran Berbasis Proyek: (1) Meningkatkan motivasi belajar peserta didik untuk belajar, mendorong kemampuan mereka untuk melakukan pekerjaan penting, dan mereka perlu untuk dihargai, (2) Meningkatkan kemampuan pemecahan masalah, (3) Membuat peserta didik menjadi lebih aktif dan berhasil memecahkan problem-problem yang kompleks, (4) Meningkatkan kolaborasi, (5) Mendorong peserta didik untuk mengembangkan dan mempraktikkan keterampilan komunikasi, (6) Meningkatkan keterampilan peserta didik dalam mengelola sumber, (7) Memberikan pengalaman kepada peserta didik pembelajaran dan praktik dalam mengorganisasi proyek, dan membuat alokasi waktu dan sumbersumber lain seperti perlengkapan untuk menyelesaikan tugas, (8) Menyediakan pengalaman belajar yang melibatkan peserta didik secara kompleks dan dirancang untuk berkembang sesuai dunia nyata, (9) Melibatkan para peserta didik untuk belajar mengambil informasi dan menunjukkan pengetahuan yang dimiliki, kemudian diimplementasikan dengan dunia nyata, dan (10) Membuat suasana belajar menjadi menyenangkan, sehingga peserta didik maupun pendidik menikmati proses pembelajaran. Penelitian yang dilakukan oleh (Ratnasari et al., 2018) menyatakan bahwa model PjBL lebih berpengaruh terhadap kemampuan representasi matematis siswa. Kemudian penelitian yang dilakukan oleh (Wati, 2018) menyatakan bahwa Model Pembelajaran Inovatif Pada Mata Pelajaran Prakarya Dan Kewirausahaan adalah model pembelajaran berbasis proyek yang diterapkan pada mata pelajaran prakarya dan kewirausahaan di Sekolah Menengah Atas/Madrasah Aliyah dan Sekolah Menengah kejuruan pada Kelas XI dengan aspek pengolahan memberikan pengaruh positif terhadap hasil siswa. Penelitian lain juga dilakukan oleh (Anggara, 2017) menyatakan bahwa penerapan pembelajaran bahasa Arab dengan model project based learning dapat meningkatkan kemampuan menulis siswa kelas VII Madrasah Tsanawiyah Nurul Huda Malang.

Selain model media juga mempunyai peran dalam proses pembelajaran. Menurut (Karo, 2018) Pemanfaatan media yang relevan di dalam kelas dapat mengoptimalkan proses pembelajaran. Bagi guru, media pembelajaran membantu mengkonkritkan konsep atau gagasan dan membantu memotivasi peserta belajar aktif. Bagi siswa, media dapat menjadi jembatan untuk berpikir kritis dan berbuat. Dengan demikian media dapat membantu tugas guru dan siswa untuk mencapai kompetensi dasar yang telah ditetapkam. Sedangkan menurut (Tafonao, 2018) Pemanfaatan media dalam pengajaran seharusnya merupakan bagian yang harus mendapat perhatian dari guru sebagai fasilitator dalam setiap kegiatan pembelajaran. Oleh karena itu setiap pendidik perlu mempelajari bagaimana memilih dan menetapkan media pembelajaran agar pencapaian tujuan pembelajaran dalam proses belajar mengajar dengan optimal. Sekalipun media pembelajaran ini masih sering diabaikan dengan berbagai alasan diantaranya. (Mahnun, 2012) menyebutkan bahwa "media" berasal dari bahasa Latin "medium" yang berarti "perantara" atau "pengantar". Lebih lanjut, media merupakan sarana penyalur pesan atau informasi belajar yang hendak disampaikan oleh sumber pesan kepada sasaran atau penerima pesan tersebut. Penggunaan media pengajaran dapat membantu pencapaian keberhasilan belajar Menurut (Sanjaya, 2010) secara umum media merupakan kata jamak dari medium, yang berarti perantara atau pengantar. Kata media berlaku untuk berbagai kegiatan atau usaha, seperti media dalam penyampaian pesan, media pengantar magnet atau panas dalam bidang teknik. Istilah media juga digunakan dalam bidang pengajaran atau pendidikan sehingga istilahnya menjadi media pendidikan atau media pembelajaran. Menurut (Sanjaya, 2010) juga menjelaskan media audio visual yaitu jenis media yang selain mengandung unsur suara juga mengandung unsur gambar yang bisa dilihat, misalnya rekaman video, film, slide suara, dan lain sebagainya. Kemampuan media ini dianggap lebih baik dan menarik.

Menurut (Steffi \& Syastra, 2015) bahwa media pembelajaran adalah segala sesuatu baik berupa fisik maupun teknis dalam proses pembelajaran yang dapat membantu guru untuk mempermudah dalam menyampaikan materi pelajaran kepada siswa sehingga memudahkan pencapaian tujuan pembelajaran yang telah dirumuskan. Media pembelajaran adalah saluran atau perantara yang digunakan untuk menyampaikan pesan atau materi ajar. Media sangat diperlukan dalam pembelajaran Produk Cake dan Kue Indonesia sebagai alat penyampaian informasi dan pesan dari guru kepada peserta didik. Pembelajaran yang baik dan berlangsung lancar memerlukan media pembelajaran yang baik dan sesuai dengan kondisi kelas. Pada mata pelajaran Produk cake dan Kue Indonesia dengan memahami hal-hal yang harus diperhatika dalam prose pembuatan kue dari tepung ketan. Oleh karena itu, video 
pembelajaran merupakan salah satu media yang sesuai untuk menampilkan sebab akibat dari dengan materi pembelajaraan secara detail dan terperinci.

Menurut (Sanjaya, 2010) juga menjelaskan media audio visual yaitu jenis media yang selain mengandung unsur suara juga mengandung unsur gambar yang bisa dilihat, misalnya rekaman video, film, slide suara, dan lain sebagainya. Media Audio visual merupakan sebuah alat bantu audio visual yang berarti bahan atau alat yang dipergunakan dalam situasi belajar untuk membantu tulisan dan kata yang diucapkan dalam menularkan pengetahuan, sikap, dan ide (Sulfemi, 2019; Saputra et al., 2018). Kemampuan media ini dianggap lebih baik dan menarik. Media video pembelajaran adalah media atau alat bantu mengajar yang berisi pesan-pesan pembelajaran. Video sebagai media audio visual dan mempunyai unsur gerak akan mampu menarik perhatian dan motivasi siswa dalam melaksanakan kegiatan pembelajaran. Menurut Kamus Besar Bahasa Indonesia (1995: 1119) mengartikan video dengan: 1) bagian yang memancarkan gambar pada pesawat televisi; 2) rekaman gambar hidup untuk ditayangkan pada pesawat televisi. Video mampu merangkum banyak kejadian dalam waktu yang lama menjadi lebih singkat dan jelas dengan disertai gambar dan suara yang dapat diulang-ulang dalam proses penggunaannya. Video memiliki kelebihan yaitu mampu membantu memahami pesan pembelajaran secara lebih bermakna tanpa terikat oleh bahan ajar lainnya. Dengan unsur gerak dan animasi yang dimiliki video, video mampu menarik perhatian siswa lebih lama bila dibandingkan dengan media pembelajaran yang lain. Media pembelajaran audio visual menunjukkan pada beberapa macam perangkat keras yang dipakai untukmenyampaikan ide dan pengalaman melalui mata dan telinga (Marhayanti, 2018). Pembelajaran dengan menggunakan media audio visual merupakan suatu cara pembelajaran yang mengandung unsur bunyi dan citra dimana proses penyampaian materi melibatkan indera penglihatan dan indera pendengaran (Saputra et al., 2018).

Penelitian yang dilakukan oleh (Ristiani Sabat et al., 2018) menyatakan bahwa penggunaan pembelajaran media Audio-Visual berbasis Example Non Example yang dilaksanakan sangat efektif dalam memahami materi kultur jaringan, dan dapat berpengaruh terhadap kemampuan berpikir kritis mahasiswa Program Studi Pendidikan Biologi STKIP SoE semester VI. Kemudian penelitian yang dilakukan oleh (Saputra et al., 2018) menyatakan bahwa penerapan model pembelajaran berbasis proyek berbantuan audio-media visual dapat meningkatkan aktivitas siswa di SMAK Suria Atambua dan SMA Negeri 1 Atambua kelas XI Pendidikan Ilmu Sosial.

Berdasarkan jabaran tersebut dapat dirumuskan sebuah tujuan penelitian tindakan ini yaitu penelitian ini bertujuan untuk menganalisis hasil belajar siiswa setelah dibelajarkan dengan model berbasis proyek dengan bantuan audio video. Perpaduan model dan media ini diharapkan dapat meningkatkan hasil bejar siswa.

\section{Metode}

Kegiatan yang dilakukan oleh peneliti pada tahap perencanaan adalah: a) Peneliti melakukan analisis kurikulum untuk menentukan standar kompetensi dan kompetensi dasar yang disampaikan kepada siswa dengan menggunakan pembelajaran dengan media interaktif, b) Membuat RPP siklus I dengan model pembelajaran dengan media interaktif, c) Membuat lembar observasi siklus I untuk melihat bagaimana kondisi belajar mengajar dikelas ketika latihan dan kerja kelompok dilaksanakan, d) Membuat Lembar Kerja Siswa siklus I, e)Membentuk kelompok yang bersifat heterogen baik dari segi kemampuan akademis, jenis pembelajaran dengan menggunakan media interaktif pada siklus I, f) Menyusun alat evaluasi pembelajaran berdasarkan perkembangan untuk dilaksanakan pada siklus II serta menyiapkan instrumen pendukung pembelajaran lainnya.

Selama pembelajaran langsung dilakukan observsi untuk mengetahui prosedur pelaksanaan pemebelajaran berbasis PBL dalam meningkatkan hasil belajar pada proses pembelajaran Cake dan Kue Indonesia. Langkah selanjutnya bagi peneliti adalah pelaksanaan. Pada tahap ini perencanaan yang sudah dibuat peneliti akan dilaksanakan dalam kegiatan pembelajaran. Tahap pengamatan atau observasi dilakukan bersamaan dengan pelaksanaan tindakan. Pada tahap ini peneliti di bantu oleh guru atau teman sejawat untuk mencatat semua hal yang diperlukan dalam penelitian berupa pengumpulan data.

Ketika dilaksanakan kegiatan pembelajaran kebanyakan siswa yang tidak tahu dan tidak paham, sehingga tidak bisa menjawab pertanyaan yang berkenaan dengan soal-soal yang berhubungan dengan "Cake dan Kue Indonesia". Karena ketidakpahaman dan ketidakmapuan dalam menjawab soal-soal yang berhubungan dengan "Cake dan Kue Indonesia", suasana kelas tampak gaduh dan sulit dikendalikan.

Tahap yang terahir merupakann kegiatan untuk mengemukakan kembali apa yang sudah dilakukan. Istilah refleksi berasal dari kata bahasa Inggris reflection yang diterjemahkan dalam bahasa Indonesia. Pada tahap ini peneliti menyimpulkan data atau hasil yang diperoleh selama proses penelitian itu berlangsung. Selain itu juga dimaksudkan sebagai upaya untuk memahami proses, masalah, persoalan, 
dan kendala nyata dalam proses tindakan. Dalam hal ini peneliti melakukan penilaian sebagai tugas akhir dari siklus.

Penelitian tindakan kelas ini dilaksanakan secara di SMKN 1 Dlanggu. Yang dijadikan subjek dalam penelitian tindakan kelas ini adalah siswa kelas XI TB 2, dengan jumlah siswa 32 orang yang terdiri dari 19 orang laki-laki dan 16 orang perempuan.

Teknik yang digunakan untuk analisis data pada penelitian ini adalah teknik deskriptif analitik dengan penjelasan sebagai berikut: Data kuantitatif yang diperoleh dari hasil tes diolah dengan menggunakan deskripsi persentase. Nilai yang diperoleh siswa dirata-rata untuk menemukan tingkat hasil belajar siswa dalam pembelajaran Cake Dan Kue Indonesia. Nilai persentase dihitung dengan ketentuan sebagai berikut:

$\mathrm{NP}=$\begin{tabular}{cc|}
$\mathrm{NK}$ & \\
- & $\mathrm{R}$
\end{tabular}

Keterangan:

$$
\begin{aligned}
& \mathrm{NP}=\text { Nilai Persentase } \\
& \mathrm{NK}=\text { Nilai Komulatif } \\
& \mathrm{R}=\text { Jumlah Responden }
\end{aligned}
$$

Data kualitatif yang diperoleh dari observasi, wawancara dan jurnal diklasifikasikan berdasarkan aspek-aspek yang dijadikan fokus analisis. Data kuantitatif dan kualitatif ini kemudian dikaitkan sebagai dasar untuk mendeskripsikan penggunaan model pembelajaran PBL, yang ditandai dengan meningkatnya hasil belajar siswa dalam pembelajaran Cake Dan Kue Indonesia secara klasikal.

\section{Hasil dan Pembahasan}

\section{Paparan Hasil Observasi Pra-siklus}

Data hasil pretes kelompok siswa sebelum mendapat Pembelajaran PBL, dianalisis dengan untuk mengetahui tingkat pengetahuan dan pemahaman tentang materi belajar yang berhubungan dengan Cake dan Kue Indonesi.

Tabel 1. Hasil Belajar Siswa Pra Siklus

\begin{tabular}{ccc}
\hline No. & Materi Ajar & Rata-rata Nilai \\
\hline 1 & Cake & 69,00 \\
2 & Kue Indonesia & 69,85 \\
\hline & Rata-Rata Nilai & $\mathbf{6 9 , 4 2 5}$ \\
\hline
\end{tabular}

Berdasarkan isi Tabel 1. terlihat bahwa nilai pretes kelompok siswa sebelum mendapat perlakuan pembelajaran dengan PBL adalah 69,425.

\section{Paparan Hasil Tindakan Siklus 1 \\ Perencanaan Tindakan Siklus 1}

Perencanaan di mulai dengan membentuk kelompok diskusi. Siswa yang berjumlah 32 siswa dibagi menjadi 5 kelompok sehingga masing-masing kelompok berjumlah 7 siswa. Materi pelajaran yang diajarkan pada siklus I ini adalah pokok bahasan cake dan kue Indonesia Proses pembelajaran ini menggunakan pendekatan permainan yang diterapkan oleh guru secara langsung dalam pembelajaran di lapangan.

Kegiatan yang dilakukan oleh peneliti pada tahap perencanaan adalah: a) Peneliti melakukan analisis kurikulum untuk menentukan standar kompetensi dan kompetensi dasar yang disampaikan kepada siswa dengan menggunakan pembelajaran dengan pembelajaran PBL Membuat RPP siklus I dengan model pembelajaran dengan pendekatan permainan, b) Membuat lembar observasi siklus I untuk melihat bagaimana kondisi belajar mengajar dikelas ketika latihan dan kerja kelompok dilaksanakan, c) Membuat Lembar Kerja Siswa siklus I, d) Membentuk kelompok (terdiri dari 5 siswa) yang bersifat heterogen baik dari segi kemampuan akademis, jenis pembelajaran dengan pendekatan permainan pada siklus I, e) Menyusun alat evaluasi pembelajaran berdasarkan perkembangan pada siklus II serta menyiapkan instrumen pendukung pembelajaran lainnya. 


\section{Pelaksanaan Tindakan Siklus 1}

Pelaksanaan kegiatan belajar mengajar pembelajaran dengan pendekatan permainan untuk siklus I dengan jumlah siswa 32 siswa. Dalam hal ini Peneliti bertindak sebagai guru. Pengamatan (observasi) dilaksanakan bersamaan dengan pelaksanaan pembelajaran. Pelaksanaan tindakan siklus I dapat diuraikan sebagai berikut: a) Guru mengawali pembelajaran dengan mengucapkan salam dan menanyakan jumlah siswa yang hadir, b) Guru melaksanakan apersepsi, c) Guru membagi siswa dalam kelompok diskusi, kemudian memberi tugas yang berkaitan dengan penggunaan pembelajaran pendekatan permainan, d) Guru memberi tugas kepada siswa untuk mempresentasikan di depan kelas hal-hal yang berkaitan dengan cake dan kue Indonesia dengan menggunakan pembelajaran PBL, waktu untuk presentasi adalah 10 menit untuk masing-masing individu, e) Guru menindaklanjuti pembelajaran itu dengan menerangkan materi pelajaran tentang hal-hal yang berkaitan dengan Produk Cake dan Kue Indonesia menggunakan pembelajaran PBL, waktu yang digunakan selama 10 menit, f) Guru bersamasama siswa mendemonstrasikan penggunaan pembelajaran pendekatan permaianan materi Produk Cake atas . selama 10 menit, g) Guru bersama-sama siswa melukukan kegiatan Praktek dengan materi produk cake dan kue Indonesia, h) Guru memberikan tugas secara individu selama 15 menit, i) Guru menutup pelajaran dengan mengucapkan salam.

Dalam siklus pertama ini, berdasarkan catatan peneliti, siswa masih kurang dapat bekerja sama, kerja kelompok masih kurang dapat berjalan sebagaimana yang diharapkan, presentasi belum banyak mendapat perhatian/tanggapan dari pendengar (siswa dari kelompok lain).

\section{Hasil Tindakan Siklus 1}

Selama pembelajaran berlangsung dilakukan observasi untuk mengetahui pengaruh kegiatan pembelajaran dalam meningkatkan hasil belajar siswa dalam pendekatan permainan dengan materi produk Cake dan Kue Indonesia Pada pembelajaran ini siswa yang masuk sebanyak 32 siswa.

Guru mengamati, ternyata pada setiap kelompok masih didapati siswa yang kurang memperhatikan pelajaran yang berkaitan dengan materi produk cake dan kue Indonesia dan masih berbicara dengan teman didekatnya tentang hal-hal yang tidak berkaitan dengan materi pembelajaran. Melalui serangkaian pertanyaan yang disampaikan kepada siswa, sebagian diantaranya belum memahami dan bahkan tidak tau apa yang di diskusikan dalam kelompoknya.

Adapun hasil belajar siswa setelah kegiatan yang diberikan dalam Siklus I, dapat dilihat di berikut: Hasil Belajar Siswa dalam Siklus 1

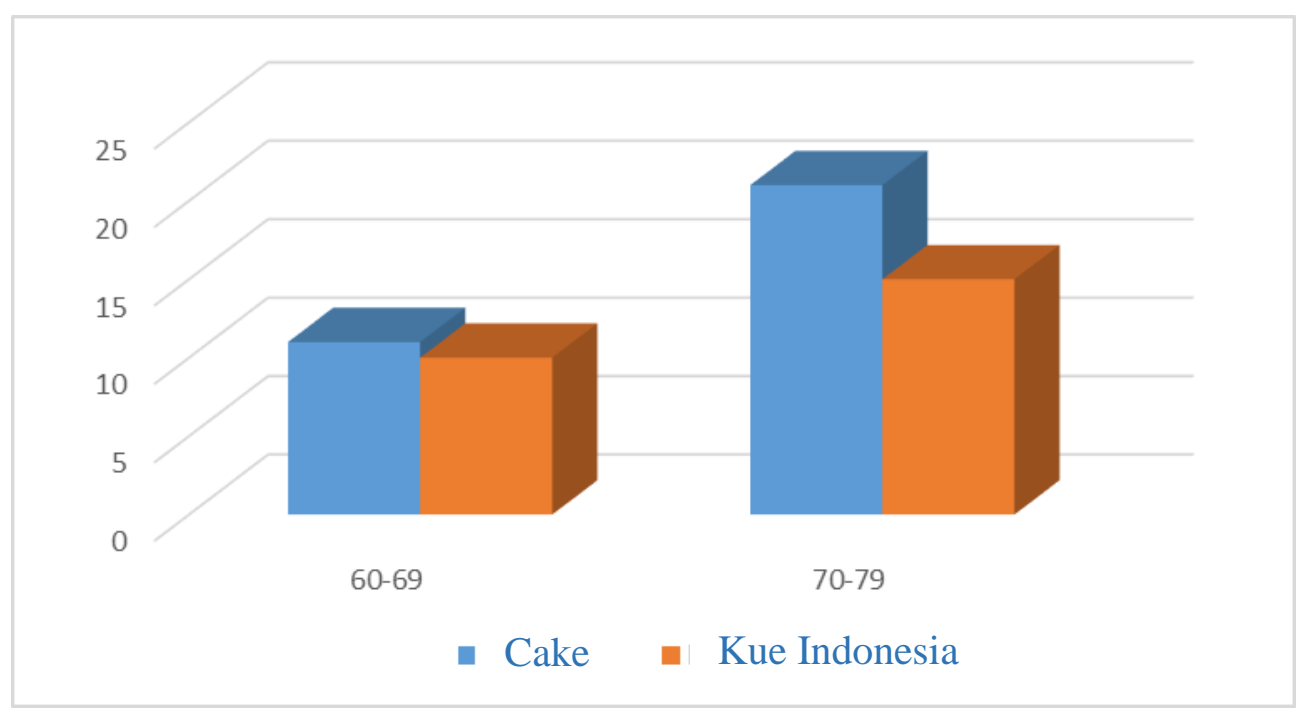

Gambar 1. Hasil Belajar Siswa dalam Siklus 1

Dari Gambar di atas dapat diketahui bahwa dengan menerapkan pembelajaran pendekatan pembelajaran pendekatan permaianan tampak bahwa nilai rata-rata siswa adalah 70,28 dengan nilai terendah 60 dan nilai tertinggi 79. Nilai ketuntasan belajar adalah 7,0 jumlah siswa yang mendapat nilai $\geq 7,0$ sebanyak 21 siswa, yang berarti $60 \%$ dari sejumlah 32 siswa memiliki nilai di atas taraf penguasaan konsep yang diberikan, lebih kecil dari persentase ketuntasan yang dikehendaki yaitu sebesar $95 \%$. Hal ini disebabkan karena siswa masih baru dan asing terhadap metode baru yang diterapkan dalam proses 
belajar mengajar. Sehingga dapat dikatakan siswa belum banyak memahami tentang konsep pokok bahasan yang dibahas.

\section{Refleksi Tindakan Siklus 1}

Dalam pelaksanaan kegiatan belajar mengajar pada siklus I yang masih terdapat kekurangankekurangan, Maka perlu adanya revisi untuk dilakukan pada siklus II antara lain : a) Guru dalam memotifasi siswa hendaknya dapat membuat siswa lebih termotivasi selama proses belajar mengajar berlangsung, b) Guru harus lebih dekat dengan siswa sehingga tidak ada perasaan takut dalam diri siswa, sehingga siswa lebih berkosentrasi dalam pembelajaran, c) Guru harus lebih bersabar dalam membimbing siswa berdiskusi untuk menemukan hal-hal baru yang berkaitan dengan materi pembelajaran, d) Guru secara intensif memberikan pengertian kepada siswa kondisi dalam berkelompok, kerjasama kelompok, dan keikutsertaan siswa dalam kelompok, e) Guru mengubah jumlah siswa (dari 7 siswa menjadi 5 siswa) dalam satu kelompok, f) Guru membantu kelompok yang belum memahami langkah-langkah pembelajaran pendekatan pembelajaran permainan, g) Guru memberikan dorongan dan motivasi kepada siswa untuk lebih aktif mencari sumber belajar, diharapkan agar siswa memperoleh hasil yang diharapkan.

\section{Paparan Hasil Tindakan Siklus II \\ Perencanaan TindakanSiklus II}

Perencanaan di mulai dengan membentuk kelompok diskusi. Siswa yang berjumlah 32 siswa dibagi menjadi 8 kelompok sehingga masing-masing kelompok berjumlah 4 siswa. Materi pelajaran yang diajarkan pada siklus II ini tetap pada pokok bahasan Produk Cake dan kue Indonesia. Proses pembelajaran pokok bahasan ini menggunakan pendekatan permainan. yang diterapkan oleh guru secara langsung dalam pembelajaran di kelas.

Kegiatan yang dilakukan oleh peneliti pada tahap perencanaan pada siklus II adalah: a) Peneliti melakukan analisis kurikulum untuk menentukan Standar Kompetensi dan Kompetensi Dasar yang disampaikan kepada siswa dengan menggunakan pendekatan permainan, b) Membuat RPP dengan model pembelajaran pendekatan permaianan siklus II, c) Membuat lembar observasi siklus II untuk melihat bagaimana kondisi belajar mengajar di kelas ketika latihan dan kerja kelompok dilaksanakan, d) Membuat Lembar Kerja Siswa siklus II, e) Membentuk kelompok (terdiri dari 4 siswi) yang bersifat heterogen baik dari segi kemampuan akademis,dengan menggunakan pembelajaran pendekatan permainan pada siklus II, f) Menyusun alat evaluasi pembelajaran berdasarkan perkembangan pada siklus II serta menyiapkan instrumen pendukung pembelajaran lainnya

\section{Pelaksanaan Tindakan Siklus II}

Pelaksanaan kegiatan belajar mengajar dengan model pembelajaran pendekatan permainan. untuk siklus II dilaksanakan di kelas XI TB 3 SMKN 1 Dlanggu dengan jumlah siswa 32. siswi materi produk cake dan kue Indonesia . Dalam hal ini Peneliti bertindak sebagai guru. Pengamatan (observasi) dilaksanakan bersamaan dengan pelaksanaan pembelajaran. Pelaksanaan tindakan disesuaikan dengan RPP (Rencana Pelaksanaan Pembelajaran) dan lembar kerja yang telah dibuat dan mengacu pada revisi siklus I, sehingga kekurangan-kekurangan pada siklus I tidak terulang pada siklus II. Adapun proses belajar mengajar mengacu pada rencana pembelajaran yang telah dipersiapkan dengan menggunakan pembelajaran permainan, dengan tahapan, presentasi kelas, kerja kelompok, tes individu, dan penghargaan kelompok.

Pelaksanaan tindakan siklus II dapat diuraikan sebagai berikut: a) Guru mengawali pembelajaran dengan mengucapkan salam dan menanyakan jumlah siswa yang hadir, b) Guru melaksanakan apersepsi, c) Guru membagi siswa dalam kelompok diskusi, kemudian memberi tugas yang berkaitan dengan penggunaan model pembelajaran PBL, d) Guru memberi tugas kepada siswa untuk mempresentasikan di depan kelas hal-hal yang berkaitan produk Cake dan Kue Indonesia dengan menggunaan model pembelajaran PBLwaktu untuk presentasi adalah 5 menit untuk masing-masing kelompok, e) Guru menindaklanjuti pembelajaran itu dengan menerangkan materi pelajaran tentang hal-hal yang berkaitan dengan materi cake dan kue indonesia atas menggunakan model pembelajaran permainan, waktu yang digunakan selama 10 menit, f) Guru bersama-sama siswa mendemonstrasikan penggunaan pembelajaran PBL materi produk cake dan kue Indonesia atas selama 10 menit, g) Guru bersama-sama siswa melukukan pembelajaran dengan materi produk cake dan kue Indonesia Guru memberikan tugas secara individu selama 15 menit, h) Guru menutup pelajaran dengan mengucapkan salam. 


\section{HasilTindakan Siklus II}

Selama pembelajaran berlangsung dilakukan observasi untuk mengetahui penerapan Permainandalam meningkatkan hasil belajar siswa dalam proses pembelajaran materi produk cake dan kue Indonesia. Pada pembelajaran ini siswa yang masuk sebanyak 32. siswa.

Bila dilihat dari angka aktivitas guru dan siswa selama kegiatan belajar mengajar, maka secara keseluruhan aktivitas guru dan siswa menunjukkan pembelajaran yang berorientasi pendekatan keterampilan proses dalam setting pembelajaran pendekatan pembelajaran PBLberpusat pada siswa, dimana siswa terlibat aktif dalam pembelajaran.

Pada akhir proses belajar mengajar siklus II siswa diberi tes dengan tujuan untuk mengetahui tingkat keberhasilan siswa dalam proses belajar mengajar yang sudah dilakukan di siklus I, kemudian dikomparasikan dengan hasil pada siklus II.

Dalam pembelajaran siklus II, konsep-konsep yang teridentifikasi dikembangkan lebih lanjut. Dalam Siklus II ini, berdasarkan catatan peneliti, kerjasama siswa sudah berjalan dengan baik, sehingga masing-masing siswa dapat memecahkan masalah secara individual. Adapun data hasil tes pada siklus II adalah sebagai berikut:

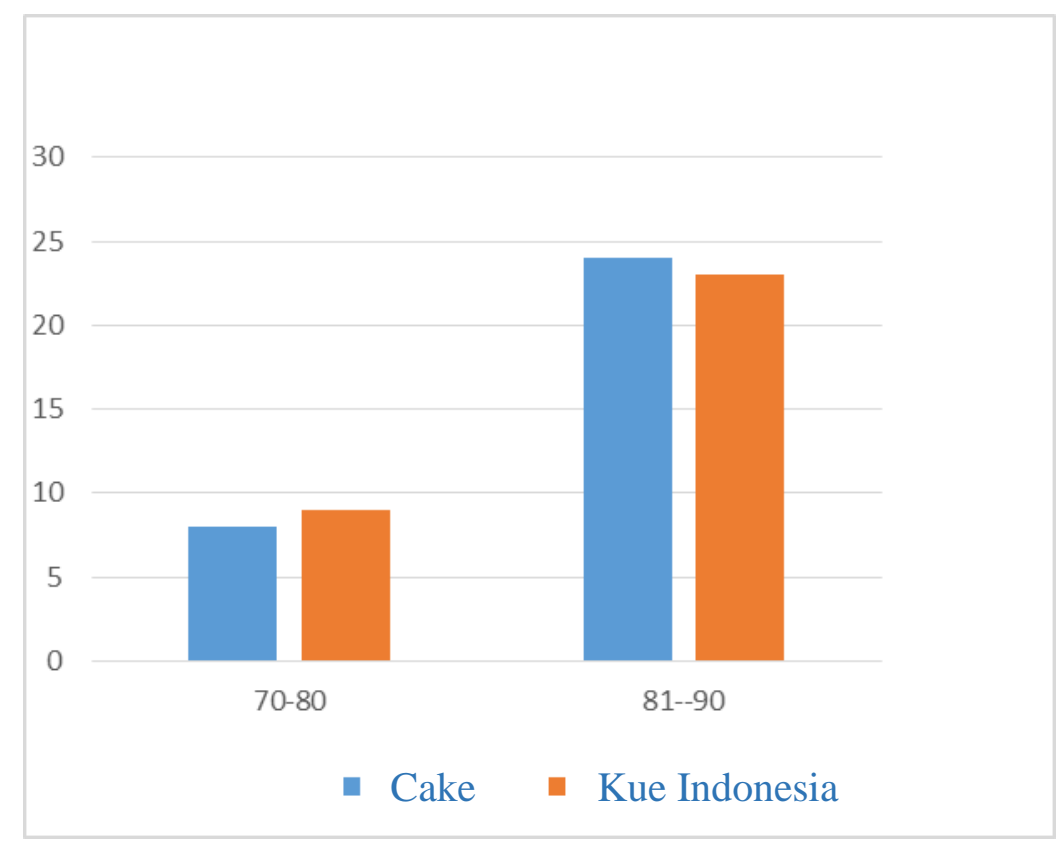

Gambar 2. Nilai Tes Formatif Siswa dalam Siklus 2

Dari tabel di atas tampak bahwa hasil nilai evaluasi rata-rata siswa secara individual adalah 80,4 dengan nilai terendah 60 dan nilai tertinggi 90 . Data diatas menunjukkan bahwa pada siklus II ini, nilai siswa secara individual mengalami peningkatan, yaitu siswa yang tuntas sebanyak 29 siswa dan yang belum tuntas sebanyak 3 siswa, yang berarti $95 \%$ dari sejumlah 32 siswa memiliki nilai di atas taraf penguasaan konsep yang diberikan. Dari siklus 2 ini dapat dikatakan bahwa proses pembelajaran dengan model pembelajaran PBL dapat meningkatkan hasil belajar siswa.

\section{RefleksiTindakan Siklus II}

Dalam pelaksanaan kegiatan belajar mengajar pada siklus II ini masih terdapat kekurangankekurangan. Pada tahap ini akan merefleksikan kembali apa yang telah dilaksanakan selama penelitian tindakan kelas dilakukan. Dari data yang diperoleh dapat diuraikan sebagai berikut: a) Selama proses belajar mengajar guru telah melaksanakan pembelajaran dengan cukup baik dengan metode pembelajaran pendekatan pembelajaran PBL, meskipun ada beberapa bagian yang masih belum sempurna, tetapi presentasi pelaksanaan untuk masing-masing kegiatan sudah cukup baik, b) Berdasarkan data hasil lembar observasi kegiatan kelompok siswa, diadakan perubahan jumlah kelompok pada siklus I sebanyak 8 siswa, dan pada siklus II sebanyak 3 siswa, c) Kekurangan pada siklus I diperbaiki, sehingga pembelajaran menjadi lebih baik pada siklus II, d) Hasil evaluasi siswa mengalami peningkatan dari siklus I ke siklus II,dan telah mencapai ketuntasan belajar pada siklus II ini sesuai yang diharapkan yakni peningkatan hasil belajar siswa. 


\section{Pembahasan Antar Siklus}

Sebelum perlakuan diberikan pada masing-masing kelompok, nilai rerata pretes siswa sebelum diberi perlakuan pembelajaran dengan Permainan adalah 69,425.Setelah siswa diberi perlakuan pembelajaran dengan Permainanpada siklus I mengalami peningkatan menjadi 70.28, namun hasil ini belum memenuhi target hasil belajar siswa mata pelajaran Penjas orkes yaitu 95\% . Bila dihitung berdasarkan nilai rerata pretes, kelompok siswa yang diberi perlakuan pembelajaran dengan Permainanseelah dilaksanaknnya siklus ke II mengalami peningkatan rerata hasil belajar sebesar 80,400$69,425=10,975$. Berdasarkan hasil pada sisklus penelitian tersebut di atas, dapat ditunjukkan bahwa ada perbedaan hasil belajar produk cake dan kue Indonesia antara siswa yang diajar menggunakan metode pembelajaran dengan dibantu model pembelajaran PBL. Dengan adanya model pembelajaran dan media akan meningkatkan hasil belajar yang lebih menyenangkan dan membuat siswa aktif mengerjakan pemecahan maslah yang diberikan. Hai ini tidak terlepas dari model yang diberikan yaitu PJBL. PJBL adalah salah satu model pembelajaran yang mengembangkan konsep kontruktivisme. PjBL merupakan model belajar yang menggunakan masalah sebagai langkah awal dalam mengumpulkan dan mengintegrasikan pengetahuan baru berdasarkan pengalamannya dalam beraktifitas secara nyata. Melalui PjBL, proses inquiry dimulai dengan memunculkan pertanyaan penuntun (a guiding question) dan membimbing siswa dalam sebuah proyek kolaboratif yang mengintegrasikan berbagai subjek (materi) dalam kurikulum. PjBL merupakan investigasi mendalam tentang sebuah topik dunia nyata, hal ini akan berharga bagi atensi dan usaha peserta didik. Adapun langkah-langkah PjBL: 1) Penentuan pertanyaan mendasar (Start With The Essention Question), 2) Mendesain perencanaan proyek (Design a Plan For The Project), 3) Menyusun jadwal (Create a Scedule), 4) Memonitor peserta didik dan kemajuan proyek (Monitor the Students and the Progress of the Project), 5) Menguji hasil (Assess the Outcome), dan 6) Mengevaluasi Pengalaman (Evaluate the Experience). Menurut (Aisah, 2014) Keuntungan Pembelajaran Berbasis Proyek: (1) Meningkatkan motivasi belajar peserta didik untuk belajar, mendorong kemampuan mereka untuk melakukan pekerjaan penting, dan mereka perlu untuk dihargai, (2) Meningkatkan kemampuan pemecahan masalah, (3) Membuat peserta didik menjadi lebih aktif dan berhasil memecahkan problem-problem yang kompleks, (4) Meningkatkan kolaborasi, (5) Mendorong peserta didik untuk mengembangkan dan mempraktikkan keterampilan komunikasi, (6) Meningkatkan keterampilan peserta didik dalam mengelola sumber, (7) Memberikan pengalaman kepada peserta didik pembelajaran dan praktik dalam mengorganisasi proyek, dan membuat alokasi waktu dan sumbersumber lain seperti perlengkapan untuk menyelesaikan tugas, (8) Menyediakan pengalaman belajar yang melibatkan peserta didik secara kompleks dan dirancang untuk berkembang sesuai dunia nyata, (9) Melibatkan para peserta didik untuk belajar mengambil informasi dan menunjukkan pengetahuan yang dimiliki, kemudian diimplementasikan dengan dunia nyata, dan (10) Membuat suasana belajar menjadi menyenangkan, sehingga peserta didik maupun pendidik menikmati proses pembelajaran. Selain model pembelajaran pengunaan media dapat meningkatkan hasil belajar. Selain itu, (Jagantara et al., 2014) menyatakan kelebihan pembelajaran berbasis proyek diantaranya mampu meningkatkan semangat pebelajar karena pebelajar selalu aktif, membantu terciptanya suasana belajar yang kondusif karena pembelajaran bersandar padamasalah dunia nyata dan memunculkan kegembiraan dalam proses belajarmengajar. Hal ini disebabkan karena proses belajar berjalan dinamis dan terbuka dari berbagai arah. Ladyana (Barlenti et al., 2017) Kelebihan LKS berbasis PjBL adalah siswatidak hanya menyelesaikan soal-soal yang berkaitan dengan materi pembelajaran, tetapi jugadituntut untuk mengaplikasikan keterampilan sains dalam kehidupan sehari-hari.

(Tafonao, 2018) Pemanfaatan media dalam pengajaran seharusnya merupakan bagian yang harus mendapat perhatian dari guru sebagai fasilitator dalam setiap kegiatan pembelajaran. Oleh karena itu setiap pendidik perlu mempelajari bagaimana memilih dan menetapkan media pembelajaran agar pencapaian tujuan pembelajaran dalam proses belajar mengajar dengan optimal. Sekalipun media pembelajaran ini masih sering diabaikan dengan berbagai alasan diantaranya. (Mahnun, 2012) menyebutkan bahwa "media" berasal dari bahasa Latin "medium" yang berarti "perantara" atau "pengantar". Lebih lanjut, media merupakan sarana penyalur pesan atau informasi belajar yang hendak disampaikan oleh sumber pesan kepada sasaran atau penerima pesan tersebut. Penggunaan media pengajaran dapat membantu pencapaian keberhasilan belajar Menurut (Sanjaya, 2010) secara umum media merupakan kata jamak dari medium, yang berarti perantara atau pengantar. Kata media berlaku untuk berbagai kegiatan atau usaha, seperti media dalam penyampaian pesan, media pengantar magnet atau panas dalam bidang teknik. Istilah media juga digunakan dalam bidang pengajaran atau pendidikan sehingga istilahnya menjadi media pendidikan atau media pembelajaran. Menurut (Sanjaya, 2010) juga menjelaskan media audio visual yaitu jenis media yang selain mengandung unsur suara juga mengandung unsur gambar yang bisa dilihat, misalnya rekaman video, film, slide suara, dan lain sebagainya. Kemampuan media ini dianggap lebih baik dan menarik. 
Menurut (Steffi \& Syastra, 2015) bahwa media pembelajaran adalah segala sesuatu baik berupa fisik maupun teknis dalam proses pembelajaran yang dapat membantu guru untuk mempermudah dalam menyampaikan materi pelajaran kepada siswa sehingga memudahkan pencapaian tujuan pembelajaran yang telah dirumuskan. Media pembelajaran adalah saluran atau perantara yang digunakan untuk menyampaikan pesan atau materi ajar. Media sangat diperlukan dalam pembelajaran Produk Cake dan Kue Indonesia sebagai alat penyampaian informasi dan pesan dari guru kepada peserta didik. Pembelajaran yang baik dan berlangsung lancar memerlukan media pembelajaran yang baik dan sesuai dengan kondisi kelas. Pada mata pelajaran Produk cake dan Kue Indonesia dengan memahami hal-hal yang harus diperhatika dalam prose pembuatan kue dari tepung ketan. Oleh karena itu, video pembelajaran merupakan salah satu media yang sesuai untuk menampilkan sebab akibat dari dengan materi pembelajaraan secara detail dan terperinci.

Menurut (Sanjaya, 2010) juga menjelaskan media audio visual yaitu jenis media yang selain mengandung unsur suara juga mengandung unsur gambar yang bisa dilihat, misalnya rekaman video, film, slide suara, dan lain sebagainya. Kemampuan media ini dianggap lebih baik dan menarik. Media video pembelajaran adalah media atau alat bantu mengajar yang berisi pesan-pesan pembelajaran. Video sebagai media audio visual dan mempunyai unsur gerak akan mampu menarik perhatian dan motivasi siswa dalam melaksanakan kegiatan pembelajaran. Menurut Kamus Besar Bahasa Indonesia (1995: 1119) mengartikan video dengan: 1) bagian yang memancarkan gambar pada pesawat televisi; 2) rekaman gambar hidup untuk ditayangkan pada pesawat televisi. Video mampu merangkum banyak kejadian dalam waktu yang lama menjadi lebih singkat dan jelas dengan disertai gambar dan suara yang dapat diulang-ulang dalam proses penggunaannya. Video memiliki kelebihan yaitu mampu membantu memahami pesan pembelajaran secara lebih bermakna tanpa terikat oleh bahan ajar lainnya. Dengan unsur gerak dan animasi yang dimiliki video, video mampu menarik perhatian siswa lebih lama bila dibandingkan dengan media pembelajaran yang lain.

Hasil penelitian ini juga didukung oleh hasil penelitian (Nugraheni, 2012) yang menyatakan bahwa ada perbedaan hasil belajar siswa yang yang mendapat perlakuan pembelajaran dengan model pembelajaran PBL memperoleh rata-rata nilai sebesar 80,400, lebih tinggi daripada sebelum siswa diajar dengan model pembelajaran lainnya, yaitu 69,425. Penerapan pembelajaran dengan Permainan memberikan peningkatatan yang lebih baik pada perolehan hasil belajar produk cake dan kue Indonesia daripada penerapan pembelajaran dengan metodel lainya. Dengan kata lain dapat diinterpretasikan bahwa penerapan pembelajaran dengan model pembelajaran PBL dapat meningkatkan perolehan hasil belajar siswa pada materi produk cake dan kue Indonesia daripada dengan model pembelajar yang lainnya.

\section{Simpulan dan Saran}

Penerapan pembelajaran dengan PBL memberikan peningkatatan yang lebih baik pada perolehan hasil belajar produk cake dan kue Indonesia daripada penerapan pembelajaran dengan metode lainya. Dengan kata lain dapat diinterpretasikan bahwa penerapan pembelajaran dengan PBL dapat meningkatkan perolehan hasil belajar siswa pada materi produk cake dan kue Indonesia daripada dengan model pembelajaran lainnya. Hal ini berdasarkan nilai rerata pretes dimana rata-rata hasil belajar siswa sebesar 69,425, sedangkan setelah siswa diberi perlakuan pembelajaran dengan PBL setelah dilaksanaknnya siklus ke II mengalami peningkatan rerata hasil belajar sebesar 80,400 artinya terjadi peningkatan rerata hasil belajar siswa sebesar 10,975.

Saran dari penelitian ini yaitu: 1) Hendaknya guru mampu menciptakan suasana kelas yang kondusif sehingga siswa tidak merasa takut; 2) Sebelum melaksanakan pembelajaran hendaknya guru mempersiapkan terlebih dahulu bahan dan alat pembelajaran demi kelancaran kegiatan; 3) Sebelum melakukan pembelajaran di kelas, Guru mampu melakukan setting kelas sesuai rencana; 4) Hendaknya guru melaksanakan model pembelajaran berbasis PBL secara konsisten. Dengan demikian diharapkan hasil belajar siswa akan lebih meningkat; 5) Hendaknya guru mengadakan kegiatan refleksi dengan guru lain dalam wadah MGMP tentang berbagai masalah pembelajaran dengan penggunaan strategi PBL yang dilakukan sehari-hari; 6) Hendaknya kepala sekolah mendukung penuh dan memberikan motivasi kepada para guru untuk selalu melaksanakan PBL guna meningkatkan hasil belajar siswa.

\section{Daftar Rujukan}

Adam. Steffi dan Muhammad Taufik Syastra. (2015). Pemanfaatan Media Pembelajaran Berbasis Teknologi Informasi Bagi Siswa Kelas X Sma Ananda Batam. Dalam CBIS Journal, Volume 3 No 2: 79. http://113.212.163.133/index.php/cbis/article/view/400

Ahmad Rohani. H.M dan Abu Ahmadi. 1991.Pengelolaan Pengajaran. Jakarta: Rineka Cipta. 
Arif S Sadiman. 2003. Media Pendidikan. Pengertian, Pengembangan, dan Pemanfaatannya.Jakarta: PT. Raja Grafindo.

Arikunto, S.2002. Prosedur Penelitian suatu pendekatan Praktek. Jakarta: Rineka Cipta.

Cheppy Riyana. 2007. Pedoman Pengembangan Media Video . Jakarta: P3AI UPI.

Depdiknas. 2006. Kurikulum Tingkat Satuan Pendidikan. Ismail, 2003. Media Pembelajaran (Model-Model Pembelajaran). Jakarta Direktorat Pendidikan Nasional.

Fathurrohman dan Sutikno. 2010. Strategi Belajar Mengajar.Bandung: Refika Aditama.

Karo S, Isran Rasyid Karo, Rohani. 2018. Manfaat Media Dalam Pembelajaran. AXIOM: Vol. VII, No. 1 Hal. 91-96. Tersedia Pada: http://jurnal.uinsu.ac.id/index.php/axiom/article/view/1778.

Marcella, Adelia, Imanuel Adhitya Wulanata, Tanti Listiani. 2018. Penerapan Team Quiz untuk Meningkatkan Kemampuan Kerja Sama Antar Siswa Kelas VIII-B pada Mata Pelajaran Matematika [The Implementation of A Team Quiz to Improve The Cooperation Skills Among Grade 8B Students in Mathematics]. JOHME: Journal of Holistic Mathematics Education Hal. 124-134. Tersdia Pada: https://ojs.uph.edu/index.php/JOHME/article/view/799.

Mahnun.Nunu. (2012). Media Pembelajaran (Kajian terhadap Langkah-langkah Pemilihan Media dan Implementasinya dalam Pembelajaran). Dalam Jurnal Pemikiran Islam; Vol. 37, No. 1: 27 http://ejournal.uin-suska.ac.id/index.php/Anida/article/view/310

Sanjaya, Wina. 2010. Strategi Pembelajaran Berorientasi Standar Proses Pendidikan. Jakarta: Kencana.

Tafonao, Talizaro. 2018. Peranan Media Pembelajaran dalam Meningkatkan Minat Belajar Mahasiswa. Jurnal Komunikasi Pendidikan, Vol.2 No.2 Hal. 103-114. Tersedia Pada: http://journal.univetbantara.ac.id/index.php/komdik/article/view/113/0

Trianto 2009. Mendesain Model Pembelajaran Inovatif - Progresif. Jakarta: Kencana Pernada Media Group.

Jagantara, I. M. W., Adnyana, P. B., \& Widiyanti, N. L. P. M. (2014). Pengaruh model pembelajaran berbasis proyek (Project Based Learning) terhadap hasil belajar biologi ditinjau dari gaya belajar siswa SMA. Jurnal Pendidikan dan Pembelajaran IPA Indonesia,4(1). http://119.252.161.254/ejournal/index.php/jurnal_ipa/article/view/1300.

Barlenti, I., Hasan, M., \& Mahidin, M. (2017). Pengembangan LKS Berbasis Project Based Learning untuk Meningkatkan Pemahaman Konsep. Jurnal Pendidikan Sains Indonesia (Indonesian Journal of Science Education), 5(1), 81-86. http://www.jurnal.unsyiah.ac.id/JPSI/article/view/8415

Anggara, S. A. (2017). Penerapan Model Project Based Learning Arabi : Journal of Arabic Studies. Arabi : Journal of Arabic Studies, 2(2), 186-196. https://doi.org/http://dx.doi.org/10.24865/ajas.v2i2.57

Marhayanti, A. (2018). Memproduksi Teks Prosedur Kompleks Menggunakan Media Audio Visual Pada Siswa SMA. Jurnal Edukasi Khatulistiwa, 1(1), 9. https://doi.org/10.26418/ekha.v1i1.24830

Mulyadi, E. (2016). Penerapan Model Project Based Learning untuk Meningkatan Kinerja dan Prestasi Belajar Fisika Siswa SMK. Jurnal Pendidikan Teknologi Dan Kejuruan, 22(4), 385. https://doi.org/10.21831/jptk.v22i4.7836

Ratnasari, N., Tadjudin, N., Syazali, M., Mujib, M., \& Andriani, S. (2018). Project Based Learning (PjBL) Model on the Mathematical Representation Ability. Tadris: Jurnal Keguruan Dan Ilmu Tarbiyah, 3(1), 47. https://doi.org/10.24042/tadris.v3i1.2535

Ristiani Sabat, D., Malaikosa, Y. L., \& Sabat, R. (2018). Efektivitas Media Audio-Visual Berbasis Example Non Example terhadap Kemampuan Berpikir Kritis Mahasiswa Program Studi Pendidikan Biologi. Teori, Penelitian, Dan Pengembangan, 304-512. https://doi.org/http://dx.doi.org/10.17977/jptpp.v3i4.10810

Saputra, I. G. N. H., Joyoatmojo, S., \& Harini, H. (2018). The implementation of project-based learning model and audio media Visual can increase students' activities. International Journal of Multicultural and Multireligious Understanding, $166-174$. https://doi.org/10.18415/ijmmu.v5i4.224 
Sulfemi, W. B. (2019). Model Pembelajaran Kooperatif Mind Mapping Berbantu Audio Visual Dalam Meningkatkan Minat, Motivasi Dan Hasil Belajar IPS. Jurnal PIPSI (Jurnal Pendidikan IPS Indonesia), 4(1), 13. https://doi.org/10.26737/jpipsi.v4i1.1204

Wati, L. F. (2018). Pembelajaran Project Based Learning Berbasis Potensi Lokal pada Mata Pelajaran Prakarya dan Kewirausahaan (SMA/SMK di Malang). Jurnal Teori Dan Praksis Pembelajaran IPS, 3(1). https://doi.org/http://dx.doi.org/10.17977/um022v3i12018p039 